\title{
Sistem Informasi Pelayanan Masyarakat Kelurahan Berbasis Web Di Kelurahan Koto Kociak Kubu Tapak Rajo
}

\author{
Restu Pratama Putra, Denny Kurniadi \\ ${ }^{1}$ Prodi Pendidikan Teknik Informatika Fakultas Teknik Universitas Negeri Padang \\ ${ }^{2}$ Dosen Jurusan Teknik Elektronika Universitas Negeri Padang \\ Jl. Prof.Hamka Kampus UNP Air Tawar Padang \\ e-mail*:rstpratama94@gmail.com
}

\begin{abstract}
Abstrak
Abstrak. Tujuan tugas akhir ini adalah untuk membangun sistem informasi pelayanan masyarakat kelurahan koto kociak kubu tapak rajo berbasis web. Kelurahan koto kociak kubu tapak rajo adalah salah satu kelurahan yang berada di kota Payakumbuh Provinsi Sumatera barat, yang salah satu dari tugasnya yaitu melaksanakan pelayanan masyarakat dilingkungan kelurahan. Teknik yang digunakan adalah Model View Controller (MVC) dan basis Framework CodeIgniter dengan sistem basis data MySQL. Hasil yang didapat berupa Sistem Informasi Pelayanan Masyarakat Kelurahan Koto Kociak Kubu Tapak Rajo berbasis web. Layanan utama applikasi meliputi pengelolaan data penduduk dan pelayanan-pelayanan pengurusan surat keterangan Pembuatan kartu tanda pengenal (KTP), surat keterangan domisili Penduduk, surat keterangan catatan kepolisian (SKCK), Surat keterangan kelahiran dan surat keterangan lainnya.
\end{abstract}

Kata Kunci: E-Government, Sistem Informasi, MySQL, E-Government, Pelayanan Masyarakat.

\begin{abstract}
Abstract. The purpose of this project is to build a web-based information system for community services in Koto Kociak sub-district Kubu Tapak Rajo. Sub-district Koto Kociak Kubu Tapak Rajo is one of the villages located in the city of Payakumbuh, West Sumatra Province, which one of its duties is to carry out community services in the village environment. The technique used is the Model View Controller (MVC) and the base CodeIgniter Framework with the MySQL database system. The results obtained are in the form of a web-based Information System for Koto Kociak Kubu Tapak Rajo. The main services of the application include managing population data and processing services for making identification cards, resident domicile certificates, police registration certificates (SKCK), birth certificates and other certificates.
\end{abstract}

Keywords: E-Government, Information Systems, E-Government, MySQL, Society Services.

\section{Pendahuluan}

Perkembangan pesat teknologi informasi yang dipercepat dengan kehadiran internet telah mendorong berbagai bidang kehidupan untuk memanfaatkan teknologi ini seoptimal mungkin. Pemanfaatan internet dalam berbagai aspek pemerintahan mendorong terwujudnya e-government, yang diharapkan dapat memberi manfaat dalam memberdayakan masyarakat melalui peningkatan akses ke informasi, meningkatkan 
layanan pemerintah kepada masyarakatnya dan memperbaiki pengelolaan pemerintahan yang lebih efisien dan transparan, salah satunya adalah pemanfaatan sistem informasi dalam membantu proses pelayanan di tingkat kelurahan (Djunaedi, 2008).

Dengan adanya otonomi daerah, maka daerah otonom memiliki hak, wewenang, dan kewajiban untuk mengatur dan mengurus sendiri urusan pemerintahan dan kepentingan masyarakat setempat sesuai dengan peraturan perundang-undangansesuai UURI No. 32 Tahun 2004 Tentang Pemerintahan Daerah (Susartono, 2006). Pemerintah kelurahan mendapatkan penugasan dari pemerintah kabupaten/kota untuk menyelenggarakan sebagian urusan administrasi kependudukan berdasarkan asas tugas pembantuan. Beberapa jenis pelayanan pelayanan yang ada pada bagian Kasi Pemerintahan yaitu surat keterangan Pembuatan kartu tanda pengenal(KTP), surat keterangan domisili Penduduk, surat keterangan catatan kepolisian (SKCK), Surat keterangan kelahiran dan surat keterangan lainnya (Republik Indonesia, 2004).

Untuk peningkatan mutu pelayanan maka dibutuhkan suatus istem pelayanan terpadu pada kelurahan sehinggapengolahan datalebih cepat dan akurat, serta mempercepat siklus informasi yang dibutuhkan dan menjadi sarana penunjang aktivitas kependudukan yang kondusif, praktis dan akurat dalam penyajian data dan informasi kependudukan (Setianto, S.H et al., 2009).

Kelurahan koto kociak kubu tapak rajo Payakumbuh Utara Kota Payakumbuh berupaya untuk melaksananakan pelayanan administrasi kependudukan dan catatan sipil kepada masyarakat sesuai prinsip-prinsip Pedoman Standar Pelayanan, namun pelayanan yang diberikan belum maksimal karena keterbatasan perangkat atau media pelayanan. Faktor-faktor yang menghambat kinerja pegawai dalam memberikan pelayanan masyarakat adalah kurangnya sumber daya manusia dalam mengimbangi tugas yang ada saat ini serta sarana dan prasarana yang masih kurang memadai pelayanan yang diberikan pihak kelurahan menjadi terbatas (Ariyadi \& Bahar, 2017).

Pada proses pelayanan adminstrasi di Kelurahan koto kociak kubu tapak rajo telah menggunakan perangkat komputer, namun penyimpanan data masih menggunakan sebuah buku besar untuk menulis data surat administrasi warga. Sementara itu, pencatatan data penduduk merupakan kegiatan yang rutin dilakukan pemerintah yang terdiri dari data pindah,data pendatang, data kelahiran dan data kematian. Hal ini menyebabkan masih banyak keluhan dan pengaduan dari masyarakat terkait prosedur yang berbelit-belit, tidak ada kepastian jangka waktu, sehingga masyarakat menilai petugas tidak professional berakibat timbulnyacitra yang kurang baik terhadap pemerintah (Hidayat, 2016; Noviyanto et al., 2014).

Berdasarkan uraian diatas, maka rumusan masalah dalam artikel ini yaitu bagaimana membangun sistem informasi pelayanan masyarakat pada kelurahan koto kociak kubu tapak rajo yang bertujuan untuk mempermudah kinerja penyelenggara pelayanan di kelurahan dan meningkatkan kualitas pelayanan aparat yang masih manual berubah menjadi sistem terkomputerisasi sehingga mempermudah pendataan dan pengarsipan data administrasi warga.

\section{Metode}

Perancangan sistem berbasis web Dibangun menggunakan bahasa pemograman Hypertext Processing (PHP) dengan MySql sebagai database dengan permodelan yang diterapkan adalah prototype. 


\subsection{Analisis Sistem}

Analisis Sistem adalah teknik pemecahan masalah yang menguraikan bagianbagian komponen dengan mempelajari seberapa bagus bagian-bagian komponen tersebut bekerja dan berinteraksi untuk mencapai tujuan mereka (Ibrahim et al., 2016). Analisis sistem merupakan tahapan paling awal dari pengembangan sistem yang menjadi fondasi dalam menentukan keberhasilan sistem informasi yang dihasilkan nantiya. Tahapan ini sangat penting karena menentukan bentuk sistem yang harus dibangun (Gaol \& Jimmy, 2008).

\subsection{Analisis Sistem yang sedang Berjalan}

analisis sistem adalah sebagai penguraian dari suatu sistem informasi yang utuh kedalam bagian-bagian komponennya dengan maksud untuk mengidentifikasikan dan mengevaluasi permasalahan -permasalahan, kesempatan-kesempatan, hambatan yang terjadi dan kebutuhan yang diharapkan sehingga dapat diusulkan perbaikan-perbaikannya. Analisis sistem tersebut dapat dilakukan dengan 3 ketentuan. Pertama, apa yang di perlukan untuk menemukan kebutuhan sesungguhnya. Kedua, alternatif apa yang bermanfaat untuk mencapa keperluan. Dan ketiga, apa keuntungan dan kerugian dari alternatif penyelesaian (Ibrahim et al., 2016; Muslihudin \& Oktafianto, 2008).

\subsection{Analisis Proses Bisnis}

Analisis proses bisnis dilakukan untuk menggambarkan berbagai proses atau aktivitas utama yang terjadi dan dilakukan pada sistem yang sedang berjalan (Ibrahim et al., 2016; Muslihudin \& Oktafianto, 2008). Berikut hasil analisis proses bisnis yang sedang berjalan pada tabel dibawah ini:

Tabel 1.Analisis proses bisnis yang sedang berjalan.

\begin{tabular}{lllc}
\hline NO & \multicolumn{1}{c}{ PROSES } & \multicolumn{1}{c}{ AKTIVITAS } & PELAKU \\
\hline 1 & Pendaftaran berkas & $\begin{array}{l}\text { Warga (pemohon) menyerahkan berkas } \\
\text { permohonan ke petugas }\end{array}$ & Warga \\
\hline 2 & Validasi berkas & $\begin{array}{l}\text { Petugas melakukan pengecekan } \\
\text { kelengkapan berkas permohonan }\end{array}$ & $\begin{array}{c}\text { Petugas } \\
\text { kelurahan }\end{array}$ \\
\hline 3 & Pembuatan berkas & $\begin{array}{l}\text { Petugas membuat berkas sesuai } \\
\text { permohonan }\end{array}$ & $\begin{array}{c}\text { Petugas } \\
\text { kelurahan }\end{array}$ \\
\hline 4 & Paraf berkas & $\begin{array}{l}\text { Kasi pemerintahan memparaf berkas } \\
\text { permohonan }\end{array}$ & $\begin{array}{c}\text { Kasi } \\
\text { pemerintahan }\end{array}$ \\
\hline 5 & $\begin{array}{l}\text { Pengajuan tanda } \\
\text { tangan berkas }\end{array}$ & $\begin{array}{l}\text { Sekretaris lurah menerima dan memeriksa } \\
\text { berkas permohonan }\end{array}$ & $\begin{array}{l}\text { Sekretaris } \\
\text { kelurahan }\end{array}$ \\
\hline 6 & $\begin{array}{l}\text { Tanda tangan } \\
\text { berkas }\end{array}$ & $\begin{array}{l}\text { Lurah menerima dan menandatangani } \\
\text { berkas }\end{array}$ & Lurah \\
\hline
\end{tabular}


Vol. 2 No. 1 Januari 2022

\begin{tabular}{cllc}
\hline 7 & Register pelayanan & $\begin{array}{l}\text { Petugas menyalin berkas untuk } \\
\text { penyimpanan ke arsip kelurahan }\end{array}$ & $\begin{array}{c}\text { Petugas } \\
\text { kelurahan }\end{array}$ \\
\hline 8 & Stempel berkas & $\begin{array}{l}\text { Pertugas memberikan stempel pada } \\
\text { dokumen asli yang sudah di tanda tangan }\end{array}$ & $\begin{array}{c}\text { Petugas } \\
\text { kelurahan }\end{array}$ \\
\hline 9 & Penyerahan berkas & $\begin{array}{l}\text { Petugas memberikan berkas yang telah } \\
\text { jadi kepada pemohon }\end{array}$ & $\begin{array}{c}\text { Petugas } \\
\text { kelurahan }\end{array}$ \\
\hline
\end{tabular}

\subsection{Analisis Aturan Bisnis}

Dalam setiap tahapan proses pelayanan-pelayanan yang tersedia terdapat aturan atau syarat yang harus dipenuhi agar dapat diproses ke tahap selanjutnya. Aturan atau syarat yang harus dipenuhi dalam tahapan tersebutakan di jelaskan di dalam tabel dibawah ini:

Tabel 2.Analisis Aturan bisnis yang sedang berjalan.

\begin{tabular}{ccl}
\hline NO & PROSES & \multicolumn{3}{c}{ ATURAN } \\
\hline 1 & $\begin{array}{c}\text { Pendaftaran } \\
\text { berkas }\end{array}$ & $\begin{array}{l}\text { Berkas yang di daftarkan harus lengkap sesuai syarat } \\
\text { pengajuan }\end{array}$ \\
\hline 2 & $\begin{array}{c}\text { Pembuatan } \\
\text { berkas }\end{array}$ & $\begin{array}{l}\text { Pembuatan berkas hanya dapat diproses jika berkas sesuai } \\
\text { dengan persyaratan pembuatan berkas }\end{array}$ \\
\hline 3 & Paraf berkas & $\begin{array}{l}\text { Kasi pemerintahan hanya memberi paraf ketika berkas yang } \\
\text { dibuat sudah sesuai dengan ketentuannya }\end{array}$ \\
\hline 4 & $\begin{array}{c}\text { Tanda tangan } \\
\text { berkas }\end{array}$ & $\begin{array}{l}\text { Lurah hanya memberi tanda tangan ketika berkas sudah diberi } \\
\text { paraf oleh kasi pemerintahan }\end{array}$ \\
\hline 5 & $\begin{array}{c}\text { Register } \\
\text { pelayanan ktp }\end{array}$ & $\begin{array}{l}\text { Petugas hanya melakukan register ke dalam asip kelurahan jika } \\
\text { dokumen tersebut telah jadi secara resmi }\end{array}$ \\
\hline 6 & $\begin{array}{l}\text { Stempel berkas } \\
\text { sudah ditanda tangani oleh lurah }\end{array}$ \\
\hline
\end{tabular}

\subsection{Flowmap yang Sedang Berjalan}

Sesuai dengan aktor yang ada.Berikut model flowmap yang sedang berjalan. Untuk lebih jelasnya dapat digambarkan pada flowmap di bawah ini: 


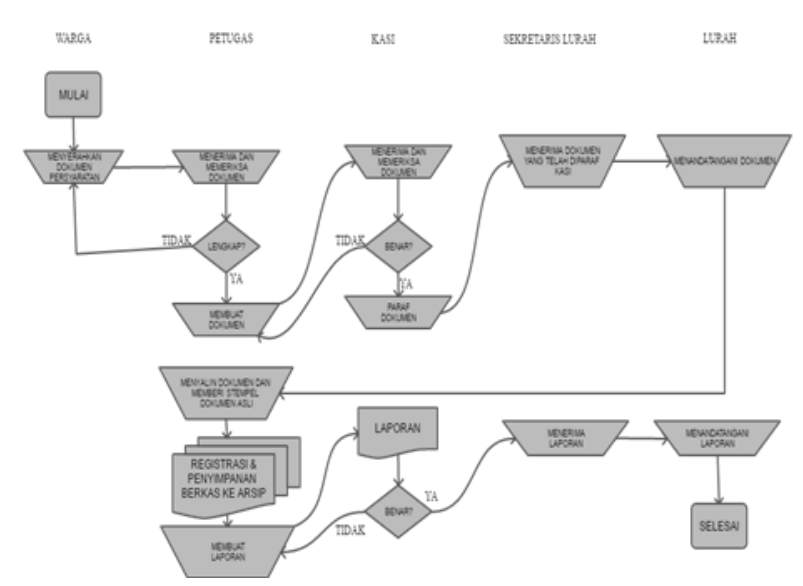

Gambar 1. Flowmap sistem yang sedang berjalan.

\subsection{Analisis Permasalahan dan Solusi}

Analisis permasalahan dan solusi dilakukan untuk merinci masalah yang dihadapi untuk kemudian dipecahkan oleh sistem yang diusulkan (Ibrahim et al., 2016).Berikut hasil analisis permasalahan dan solusi yang sedang berjalan.

Tabel 3.Hasil analisis permasalahan dan solusi.

\begin{tabular}{|c|c|c|}
\hline No & Masalah & Solusi \\
\hline 1 & $\begin{array}{lr}\text { Pelayanan } & \text { yang } \\
\text { lambat dan } \\
\text { jumlah } \\
\text { yang di layanani } \\
\text { tidak seimbang. }\end{array}$ & $\begin{array}{l}\text { Dengan adanya } \\
\text { system } \\
\text { pelayanan dapat } \\
\text { di lakukan } \\
\text { secara online. }\end{array}$ \\
\hline 2 & $\begin{array}{l}\text { Kelengkapan } \\
\text { administrasi } \\
\text { berkas-berkas } \\
\text { pemohon yang } \\
\text { kurang lengkap } \\
\text { saat melakukan } \\
\text { pendaftaran } \\
\text { berkas karena } \\
\text { kurangnya } \\
\text { informasi tentang } \\
\text { berkas yang } \\
\text { dibutuhkan untuk } \\
\text { melakukan } \\
\text { pendaftaran } \\
\text { berkas. }\end{array}$ & $\begin{array}{l}\text { Pihak kelurahan } \\
\text { dapat melakukan } \\
\text { sosialiasi } \\
\text { melalui RT/RW } \\
\text { untuk } \\
\text { menjelaskan hal- } \\
\text { hal terkait syarat } \\
\text { dan tata cara } \\
\text { dari proses } \\
\text { pelayanan- } \\
\text { pelayanan yang } \\
\text { ada di } \\
\text { kelurahan. }\end{array}$ \\
\hline 3 & $\begin{array}{ll}\text { Sering } & \text { terjadi } \\
\text { kesalahan dalam } \\
\text { pengecekan } \\
\text { berkas akibat }\end{array}$ & $\begin{array}{l}\text { Pengecekan } \\
\text { berkas akan } \\
\text { dilakukan oleh } \\
\text { system sehingga }\end{array}$ \\
\hline
\end{tabular}




$\begin{array}{ll}\text { kurang telitinya } & \text { resiko kesalah- } \\ \text { petugas kelurahan } & \text { an dapat di } \\ \text { dalam melakukan } & \text { minimalisir oleh } \\ \text { pengecekan } & \text { sistem } \\ \text { administrasi } & \\ \text { berkas. } & \end{array}$

\subsection{Analisis sistem yang diusulkan}

Sistem yang dikembangkan akan melibatkan sepuluh level pengguna sistem yang terdiri dari admin, operator, penduduk, rt, rw, urusan tata usaha dan umum, seksi pemerintahan, seksi kesejahteraan, sekretaris lurah dan lurah. Pengguna akan berinteraksi dengan sistem menggunakan basis data yang terdapat pada sistem informasi.

\subsection{Analisis User} berikut:

Berikut aktivitas-aktivitas user yang terdapat dalam sistem dijelaskan pada tabel

Tabel 4.Analisis User.

\begin{tabular}{|c|c|c|}
\hline No & User & Aktivitas \\
\hline 1 & Admin & $\begin{array}{l}\text { User yang memiliki hak akses untuk menambahkan data-data dasar } \\
\text { sistem seperti data level user. }\end{array}$ \\
\hline 2 & Operator & $\begin{array}{l}\text { User yang bertugas untuk menambahkan user yang diberikan hak } \\
\text { akses ke dalam sistem. }\end{array}$ \\
\hline 3 & Penduduk & $\begin{array}{l}\text { User yang menjadi salah satu sumber masukan data dan informasi } \\
\text { dalam sistem, dan memiliki hak akses untuk mengelola data dan } \\
\text { informasi yang berhubungan dengan penduduk itu sendiri. }\end{array}$ \\
\hline 4 & Rt & $\begin{array}{l}\text { User yang menjadi salah satu sumber masukan data dan informasi } \\
\text { dalam sistem. RT bertugas untuk memasukkan data penduduk } \\
\text { sebagai data awal dari sistem. }\end{array}$ \\
\hline 5 & $\mathrm{Rw}$ & $\begin{array}{l}\text { Salah satu user yang menjadi sumber masukan data dan informasi } \\
\text { dalam sistem, dan RW memiliki hak akses untuk mengelola data } \\
\text { dan informasi terkait kewilayahannya. }\end{array}$ \\
\hline 6 & $\begin{array}{l}\text { Urusan TU } \\
\text { dan Umum }\end{array}$ & $\begin{array}{l}\text { User yang memiliki hak akses untuk mengelola data dan informasi } \\
\text { terkait Administrasi Umum.. }\end{array}$ \\
\hline 7 & $\begin{array}{c}\text { Seksi } \\
\text { pemerintahan }\end{array}$ & $\begin{array}{l}\text { User yang memiliki hak akses untuk mengelola data dan informasi } \\
\text { mengenai Administrasi Kependudukan. }\end{array}$ \\
\hline 8 & $\begin{array}{c}\text { Seksi } \\
\text { kesejahteraan }\end{array}$ & $\begin{array}{l}\text { User yang memiliki hak akses untuk mengelola data dan informasi } \\
\text { sosial masyarakat. }\end{array}$ \\
\hline 9 & $\begin{array}{l}\text { Sekretaris } \\
\text { lurah }\end{array}$ & $\begin{array}{l}\text { User yang memiliki hak akses untuk memeriksa dan } \\
\text { mengkonfirmasi seluruh data dan informasi yang telah dimasukkan } \\
\text { oleh Perangkat Kelurahan untuk dapat diteruskan kepada Lurah. } \\
\text { Jika Lurah tidak ada ditempat, maka Sekretaris Lurah dapat } \\
\text { mencetak dokumen diperlukan dari sistem. }\end{array}$ \\
\hline
\end{tabular}


Vol. 2 No. 1 Januari 2022

User yang memiliki hak akses mencetak data dan informasi untuk

10 Lurah selanjutnya dapat diserahkan kepada pihak yang memerlukan data dan informasi tersebut dan dapat memeriksa dan mengkonfirmasi data dan informasi jika Sekretaris Lurah berhalangan

\subsection{Analisis Data dan Dokumen}

Data dan Dokumen di dalam proses sistem terdapat dua jenis yaitu Data dan Dokumen Input serta Data dan Dokumen Output. Data dan dokumen dari masing-masing jenis dapat dijabarkan sebagai berikut:

1. Data dan dokumen input

Data dan Dokumen Input merupakan data dan dokumen yang dibutuhkan untuk masukan sistem. Berikut seluruh data dan dokumen yang dibutuhkan untuk masukan Sistem Informasi Pelayanan Masyarakat.

Tabel 5.Data dan Dokumen Input.

\begin{tabular}{|c|c|c|c|}
\hline NO & KEGIATAN & DOKUMEN & DATA \\
\hline 1 & $\begin{array}{l}\text { Input Data } \\
\text { Penduduk }\end{array}$ & $\begin{array}{l}\text {-Akta } \\
\text { Kelahiran } \\
\text {-Ijazah } \\
\text { Pendidikan } \\
\text {-Buku Nikah } \\
\text {-Paspor } \\
\text {-KTP }\end{array}$ & $\begin{array}{l}\text { NIK, Nama, Jenis Kelamin, Tempat } \\
\text { Lahir, Tanggal Lahir, Agama, Golongan } \\
\text { Darah, Status Perkawinan, Kelainan, } \\
\text { Pendidikan Terakhir, Pekerjaan, } \\
\text { Kewarganegaraan, Nomor Paspor, } \\
\text { Tanggal Paspor, Nomor Akta Kelahiran, } \\
\text { Nomor Akta Perkawinan, Nomor Akta } \\
\text { Perceraian, Nama Ibu, Nama Ayah, } \\
\text { Nomor Telepon, Status }\end{array}$ \\
\hline 2 & $\begin{array}{l}\text { Input Data } \\
\text { Keluarga }\end{array}$ & $\begin{array}{l}\text {-Kartu } \\
\text { Keluarga }\end{array}$ & Nomor KK, Alamat \\
\hline 3 & $\begin{array}{l}\text { Input Data } \\
\text { Kelahiran }\end{array}$ & $\begin{array}{l}\text {-Surat } \\
\text { Keterangan } \\
\text { Kelahiran dari } \\
\text { RS } \\
\text {-KK } \\
\text {-Buku Nikah }\end{array}$ & $\begin{array}{l}\text { NIK, Nama, Tempat Lahir, Tanggal } \\
\text { Lahir, Agama, Golongan Darah, Tempat } \\
\text { Dilahirkan, Jam Kelahiran, Jenis } \\
\text { Kelahiran, Anak Ke-, Penolong } \\
\text { Kelahiran, Berat Bayi, Panjang Bayi, } \\
\text { NIK Ibu, NIK Ayah, NIK Pelapor, NIK } \\
\text { Saksi Pertama, NIK Saksi Kedua }\end{array}$ \\
\hline 4 & $\begin{array}{l}\text { Input Data } \\
\text { Kematian }\end{array}$ & $\begin{array}{l}\text {-Surat } \\
\text { Keterangan } \\
\text { Kematian Dari } \\
\text { Rumah Sakit }\end{array}$ & $\begin{array}{l}\text { NIK, Tempat Wafat, Tanggal Wafat, Jam } \\
\text { Wafat, Tempat \& Tanggal Dikebumikan }\end{array}$ \\
\hline
\end{tabular}


Vol. 2 No. 1 Januari 2022

\begin{tabular}{|c|c|c|c|}
\hline 5 & $\begin{array}{l}\text { Input Data } \\
\text { Domisili }\end{array}$ & $\begin{array}{l}\text {-Surat Pindah } \\
\text {-Dokumen } \\
\text { Input Data } \\
\text { Penduduk }\end{array}$ & $\begin{array}{l}\text { Nomor KK Asal, Nama Kepala Keluarga } \\
\text { Asal, Alamat Asal, Tanggal Pindah, } \\
\text { Maksud Kepindahan, Data Input Data } \\
\text { Penduduk }\end{array}$ \\
\hline 6 & $\begin{array}{l}\text { Input Data } \\
\text { Pindah }\end{array}$ & $\begin{array}{l}\text {-Surat Pindah } \\
\text {-Dokumen } \\
\text { Input Data } \\
\text { Penduduk }\end{array}$ & $\begin{array}{l}\text { Nomor KK Asal, Jenis Kepindahan, } \\
\text { Status Anggota Keluarga yang tidak } \\
\text { pindah, Status Anggota Keluarga bagi } \\
\text { yang pindah, Nomor KK Tujuan, NIK } \\
\text { Kepala Keluarga Tujuan, Nama Kepala } \\
\text { Keluarga Tujuan, NIK penduduk yang } \\
\text { pindah }\end{array}$ \\
\hline 7 & $\begin{array}{l}\text { Input Data } \\
\text { Register } \\
\text { Surat }\end{array}$ & -KTP & NIK, Keperluan Surat \\
\hline 8 & $\begin{array}{l}\text { Input Data } \\
\text { Agenda Surat } \\
\text { Masuk }\end{array}$ & -Surat Masuk & $\begin{array}{l}\text { Nomor Index, Kode Surat, Tanggal } \\
\text { Terima Surat, Nomor Surat, Tanggal } \\
\text { Surat, Asal Surat, Perihal Surat }\end{array}$ \\
\hline 9 & $\begin{array}{l}\text { Input Data } \\
\text { Agenda Surat } \\
\text { Keluar }\end{array}$ & -Surat Keluar & $\begin{array}{l}\text { Nomor Index, Kode Surat, Tanggal } \\
\text { Surat, Perihal, Tujuan Surat }\end{array}$ \\
\hline
\end{tabular}

2. Data dan dokumen output

Data dan Dokumen Output merupakan data dan dokumen yang diperoleh dari keluaran sistem. Berikut data dan dokumen yang akan diperoleh dari keluaran Sistem Informasi Pelayanan Masyarakat.

Tabel 6.Data dan Dokumen Output.

\begin{tabular}{llll}
\hline NO & \multicolumn{1}{c}{ KEGIATAN } & \multicolumn{1}{c}{ DOKUMEN } & \multicolumn{1}{c}{ DATA } \\
\hline 1 & Administrasi Penduduk & -Laporan Rekapitulasi & -Data Keluarga \\
& Penduduk & -Data Penduduk \\
& & -Surat Pindah / Surat & -Data Rekapitulasi \\
& Domisili & Penduduk \\
& & -Surat Kematian / Surat & \\
\hline
\end{tabular}


Vol. 2 No. 1 Januari 2022

\begin{tabular}{llll}
\hline & Kelahiran & \\
\hline Administrasi Pelayanan & - Surat Rekomendasi KTP & -Data Register \\
Seksi Pemerintahan & - Surat Rekomendasi KK & Surat \\
& - Surat Rekomendasi & -Nomor Register \\
& Perubahan KK & Surat \\
& - Surat Rekomendasi & \\
& Penduduk Datang & \\
& - Surat Rekomendasi & \\
& Pindah & \\
& - Surat Rekomendasi & \\
& Domisili & \\
& - Surat Rekomendasi & \\
& Surat Kematian & \\
& - Surat Rekomendasi & \\
& Surat Kelahiran & \\
& - Surat Rekomendasi & \\
& Keterangan kehilangan & \\
& - Surat Rekomendasi & \\
& surat-surat lainnya. & \\
\hline
\end{tabular}

\subsection{Flowmap yang Diusulkan}

Berdasarkan gambar dibawah ini, menjelaskan bahwa sistem yang akan di usulkan dinilai dapat mengatasi permasalahan-permasalahan yang ditimbulkan oleh sistem yang sedang berjalan sebelumnya karena sistem akan menjadikan proses lebih terstruktur dan menggunakan database sebagai penyimpanan. Flowmap yang di usulkan sebagai berikut:

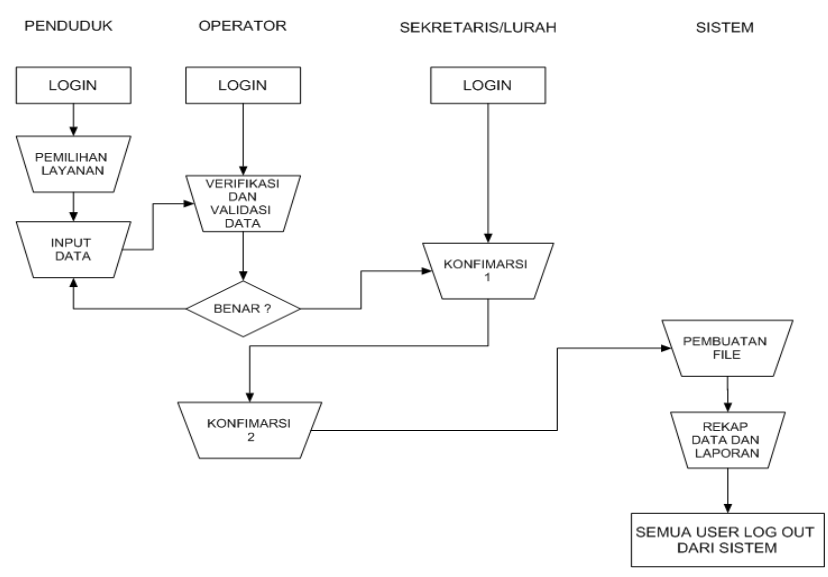

Gambar 2. Flowmap yang di usulkan.

\subsection{Perancangan Sistem}

Perancangan sistem merupakan antarmuka pengguna dan program aplikasi menggunakan basis data melalui pemodelan (Muslihudin \& Oktafianto, 2008).Untuk membangun sistem ini, perlu pemodelan-pemodelan yang digunakan. 


\subsubsection{Diagram konteks}

Diagram konteks merupakan suatu diagram alur tingkat tinggi yang menggambarkan seluruh jaringan, masukan dan keluaran.Diagram konteks berisi siapa saja yang memberikan data masukan ke sistem serta kepada siapa data informasi yang harus dihasilkan sistem (Ibrahim et al., 2016; Subhan, n.d.). Adapun diagram konteks yang diusulkan untuk sistem ini sebagai berikut:

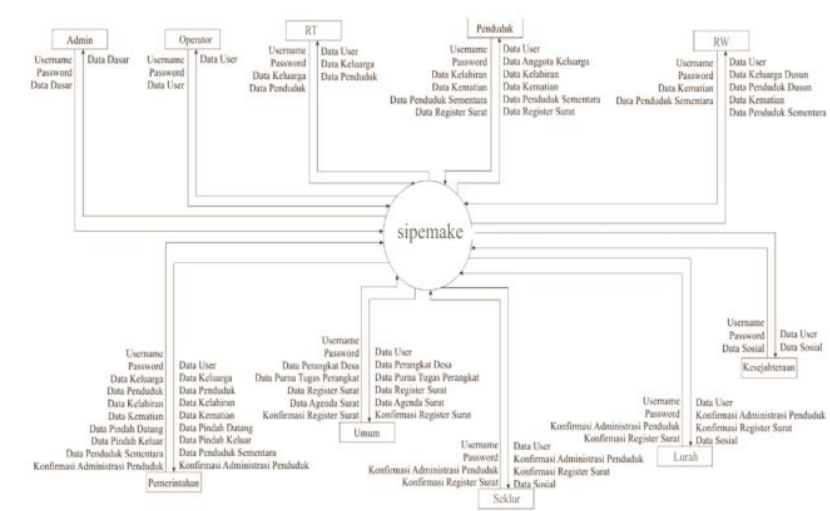

Gambar 3. Rancangan Diagram Konteks.

\subsubsection{Use Case Diagram}

Use case diagram menggambarkan funsionalitas dari sebuah sistem berdasarkan sudut pandang aktor. Use case diagramsistem yang diusulkan sebagai berikut:

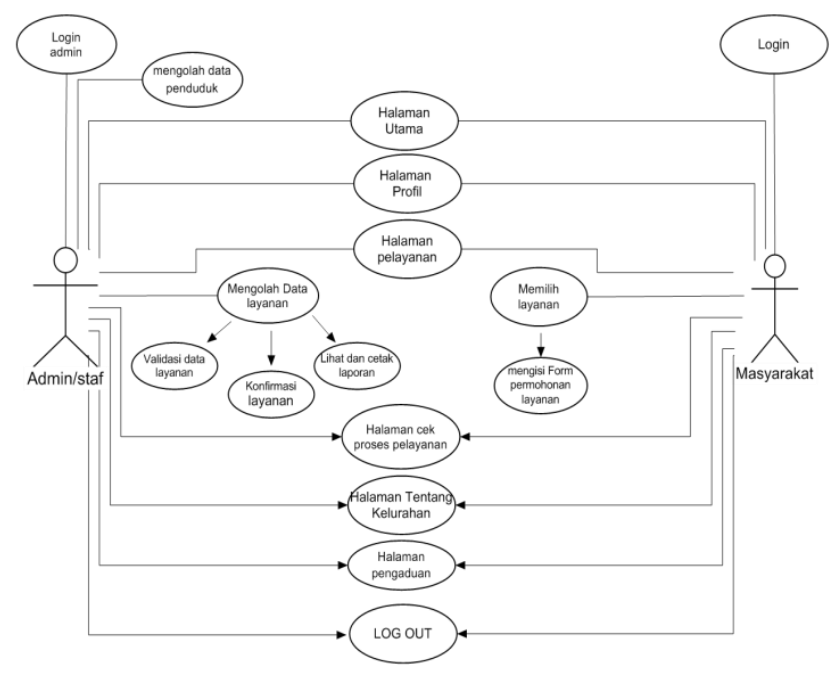

Gambar 4. Use case Diagram

\subsubsection{Activity Diagram}

Activity diagram merupakan diagram yang menggambarkan berbagai aliran aktivitas yang terjadi di dalam sistem yang meliputi bagaimana sebuah proses dapat 
terjadi, kemungkinan -kemungkinan yang bisa terjadi, serta bagaimana akhir dari proses tersebut.

\section{Activity Diagram Login}

Pada aktivitas ini, setiap user diharuskan memasukkan usename, password, dan captcha ke dalam formlogin.

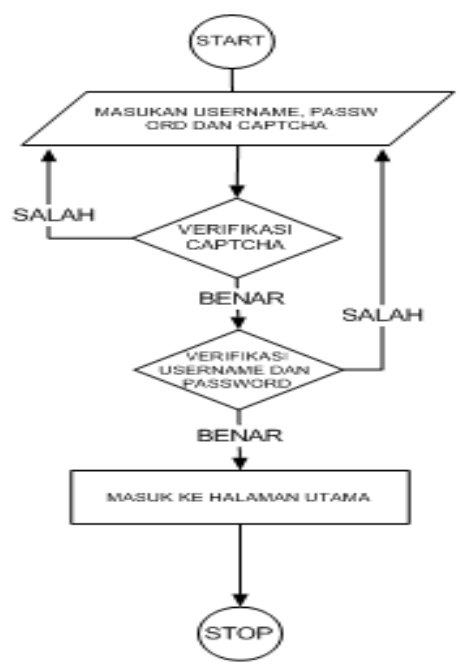

Gambar 5. Activity Diagram Login

\section{Activity Diagram Input Data Penduduk}

Aktivitas ini dilakukan pada saat user operator telah melakukan login ke dalam sistem.. Dapat digambarkan melalui diagram berikut :

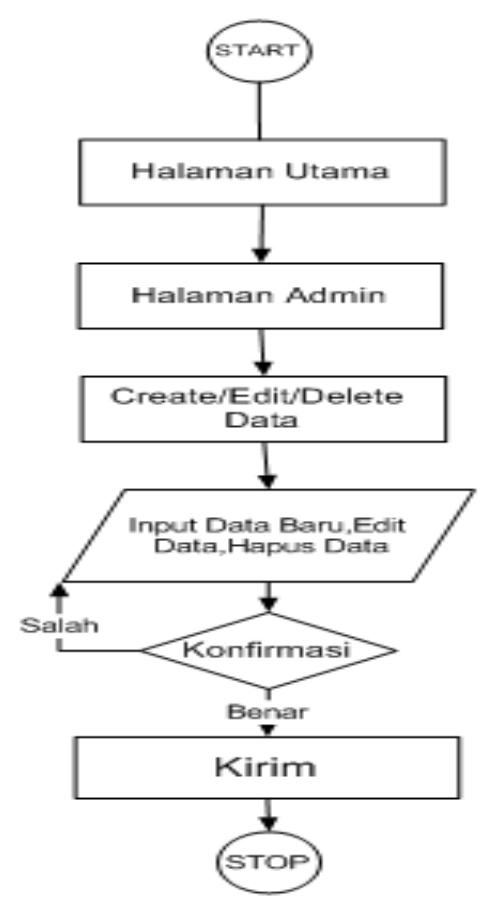

Gambar 6. Activity Diagram Input Data Penduduk 


\section{Activity Diagram Administrasi Layanan Penduduk}

Aktivitas ini dilakukan pada saat user penduduk telah melakukan login ke dalam sistem dan ingin mengajukan permohonan pelayanan yang tersedia pada sistem. Dapat digambarkan melalui diagram berikut :

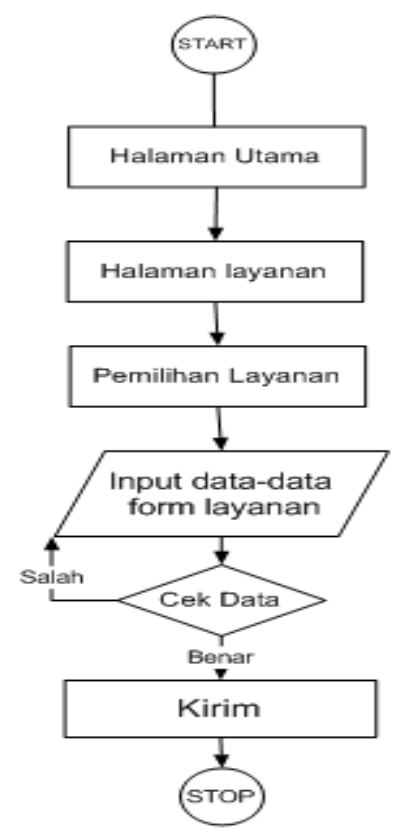

Gambar 7. Activity Diagram Administrasi Pelayanan Penduduk

\subsection{Perancangan Database}

Perancangan basis data adalah perancangan yang sangat penting dalam pembuatan suatu sistem informasi. Perancangan basis data dilakukan agar tidak terjadi redudansi data, duplikasi data dan inkonsistensi data sehingga sistem yang dibangun menghasilkan informasi yang bermamfaat sesuai dengan tujuan sistem (Fathansyah, 2012).

\subsubsection{Entity Relationship Diagram (ERD)}

Dalam merancang suatu basis data, diperlukan entity relationship diagram untuk menggambarkan entitas (aktor) yang berperan dalam sebuah basis data serta hubungan antar aktor-aktor yang berperan tersebut (Fathansyah, 2012). Kelas entitas dilambangkan dengan segi empat, hubungan di lambangkan dengan ketupat, dan kardinalitas maksimun hubungan diperlihatkan dalam ketupat ERD ini sesuai dengan struktur table dan sudah pada tingkat normal ketiga (3NF). ERD yang digunakan untuk pemodelan basis data pada sistem ini adalah sebagai berikut: 
Vol. 2 No. 1 Januari 2022

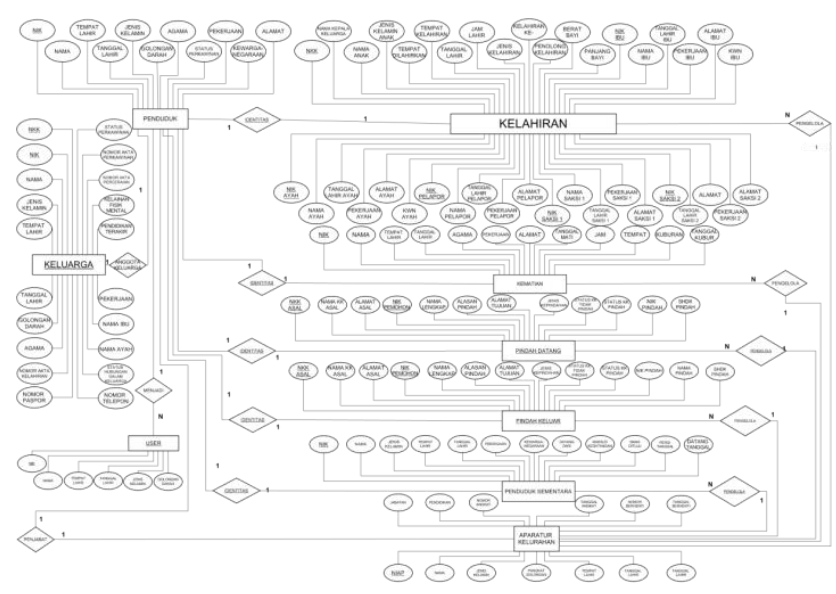

Gambar 8.Entity Relationship Diagram

\subsection{Rancangan Interface}

Rancangan Interface merupakan rancangan antarmuka atau tampilan yang menghubungkan antara pengguna dengan sistem informasi pengelolaan layanan kajian dhuha. Perancangan antarmuka harus bersifat nyaman dilihat, mudah digunakan dan mudah dipahami oleh pengguna (Gaol \& Jimmy, 2008).

\section{Rancangan Interface Halaman Login}

Halaman Login merupakan halaman awal yang ditampilkan kepada user setelah mengakses alamat web Sistem Informasi pelayanan masyarakat.

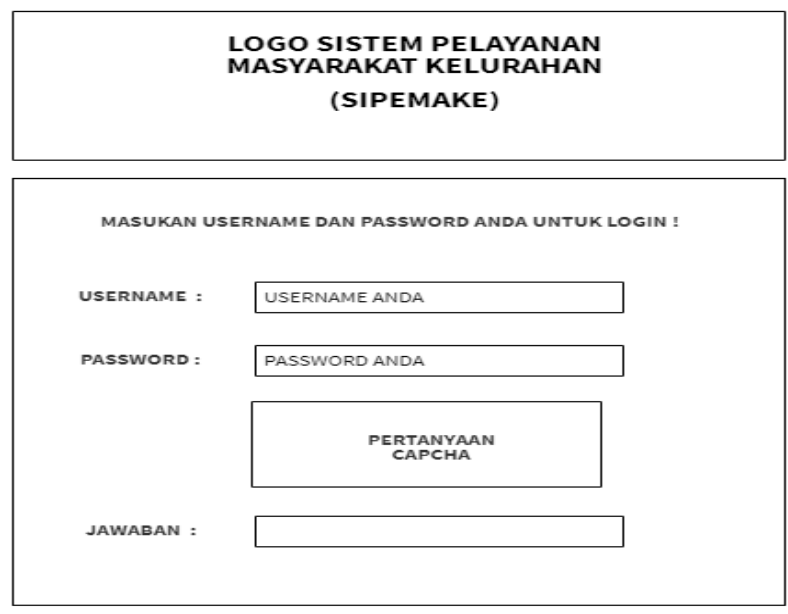

Gambar 9.Rancangan Halaman Login

\section{Rancangan Interface Halaman Home}

Setelah setiap user berhasil melakukan login, maka user akan masuk ke dalam sistem dengan tampilan pertama yaitu halaman home. Pada halaman home terdiri dari bagian header, footer, menu, dan content. 


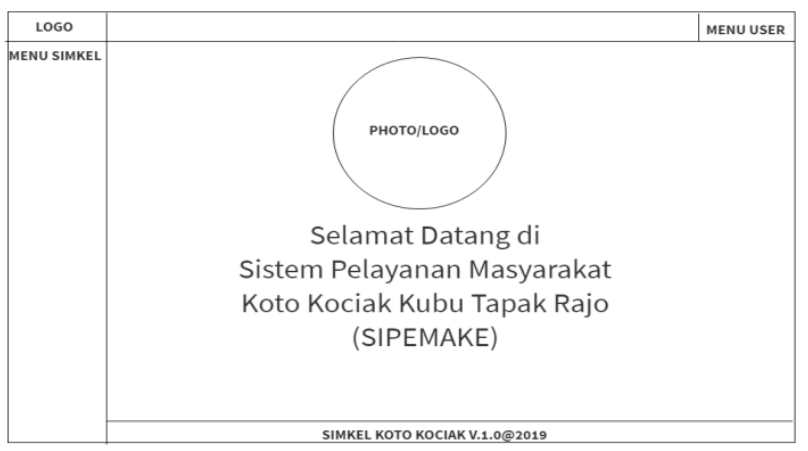

Gambar 10.Rancangan Halaman Home

\section{Rancangan Interface Halaman Profil} akses sistem.

Halaman profil menampilkan informasi lengkap mengenai user yang melakukan

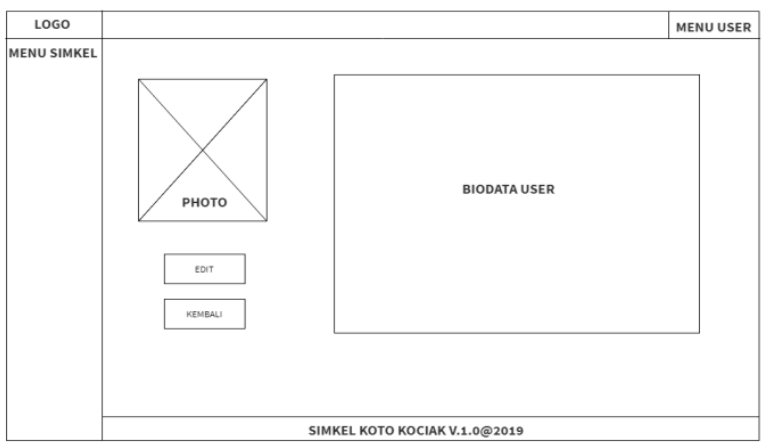

Gambar 11.Rancangan Halaman Profil

\section{Hasil dan Pembahasan}

Hasil dan pembahasan sistem informasi pengelolaan layanan kajian dhuha menampilkan halaman depan, halaman pendaftar dan login, halaman kartu peserta kajian dhuha, evaluasi kajian dhuha, dan laporan kajian dhuha.

\section{Hasil Halaman Login}

Halaman login merupakan halaman pertama yang diakses oleh user setelah mengakses web Sistem Informasi Pelayanan Masyarakat Kelurahan. Pada halaman ini user harus memasukkan username, password, dan captcha berupa perhitungan matematika.

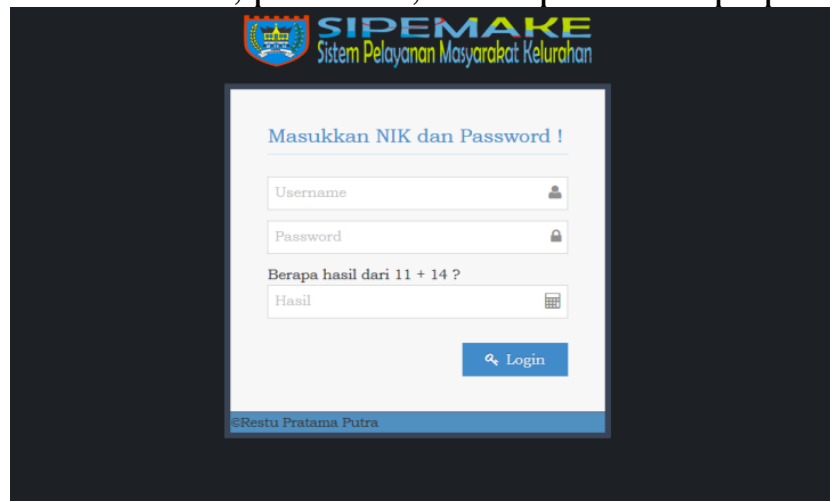

Gambar 12.Hasil Halaman Login 


\section{Hasil Halaman Home Admin}

Halaman home merupakan halaman pertama yang diakses oleh user setelah berhasil melakukan login. Halaman home terdiri dari bagian header, menu, content, dan footer. Bagian menu setiap user berbeda sesuai dengan hak akses masing-masing user. Bagian content pada halaman ini dapat berubah sesuai tombol menu ataupun tombol aksi yang diklik oleh user.

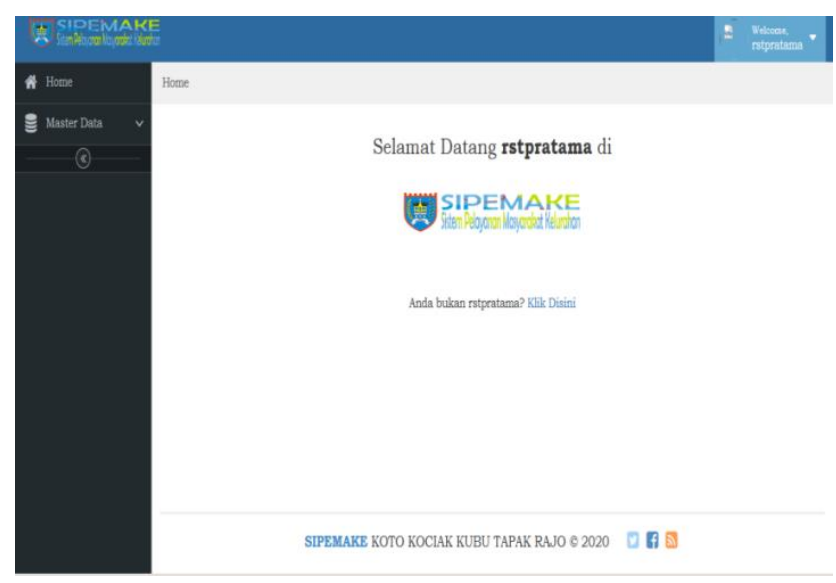

\section{Gambar 13.Hasil Halaman Admin}

\section{Hasil Halaman Home Operator}

Halaman home operator terdiri dari menu home untuk kembali ke halaman awal dan menu daftar user untuk mengelola data user yang diberikan hak akses masuk ke dalam sistem.

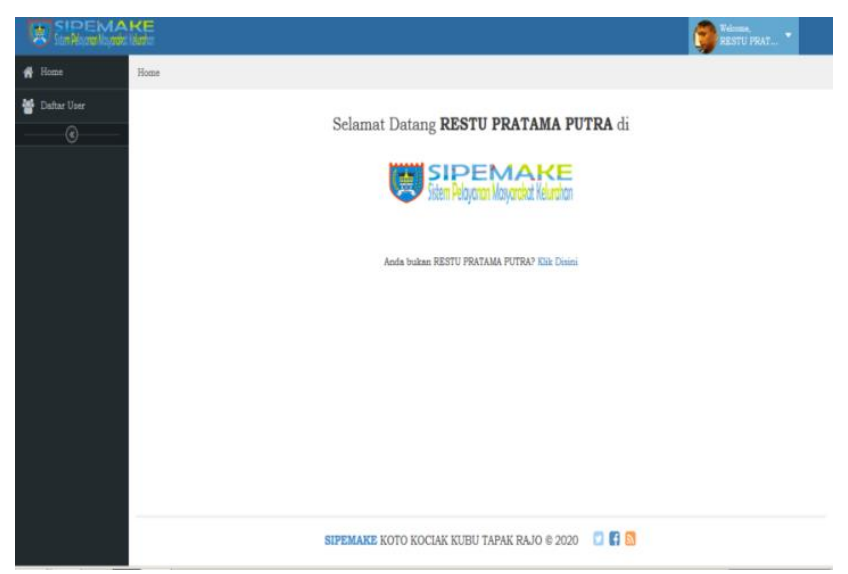

Gambar 14.Rancangan Halaman Operator

\section{Hasil Halaman Home RT}

Pada interface halaman home lurah terlihat tampilan menu terdiri dari home, keluarga, penduduk, ekonomi. 


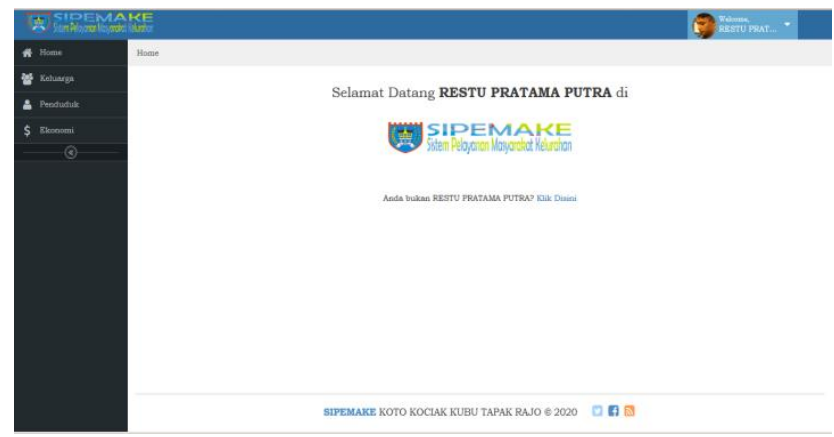

\section{Hasil Halaman Home RW}

Gambar 15.Hasil Halaman Home RT

Pada interface halaman home rw menampilkan menu home, keluarga, penduduk, dan lapor. Menu lapor juga memiliki submenu kematian dan penduduk sementara.

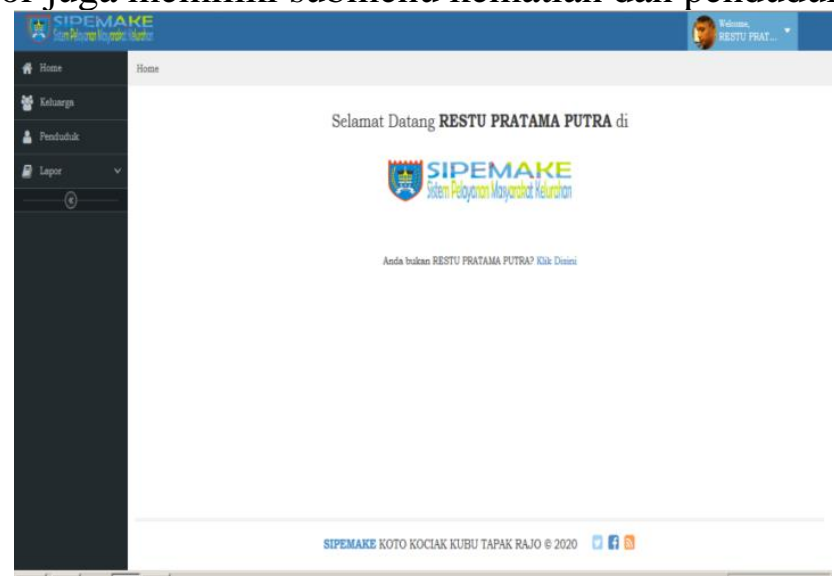

\section{Hasil Halaman Home Penduduk}

\section{Gambar 16.Hasil Halaman Home RW}

Pada gambar interface halaman home penduduk terdiri dari menu home, keluarga, lapor, dan register surat. Menu lapor juga memiliki submenu yaitu kelahiran, kematian, dan penduduk sementara.

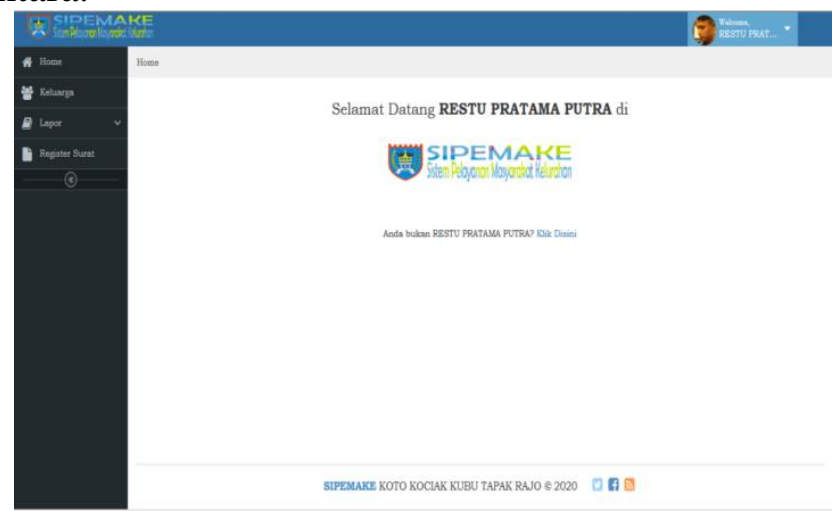

Gambar 16.Hasil Halaman Home Penduduk

\section{Hasil Halaman Home Pemerintahan}

Pada interface halaman home bagian pemerintahan menampilkan menu home, keluarga, penduduk, administrasi, konfirmasi, dan konfirmasi ditolak. Menu keluarga berfungsi untuk mengelola data keluarga seperti melihat, menambah, dan edit data keluarga serta melihat, menambah, dan edit data anggota keluarga. 


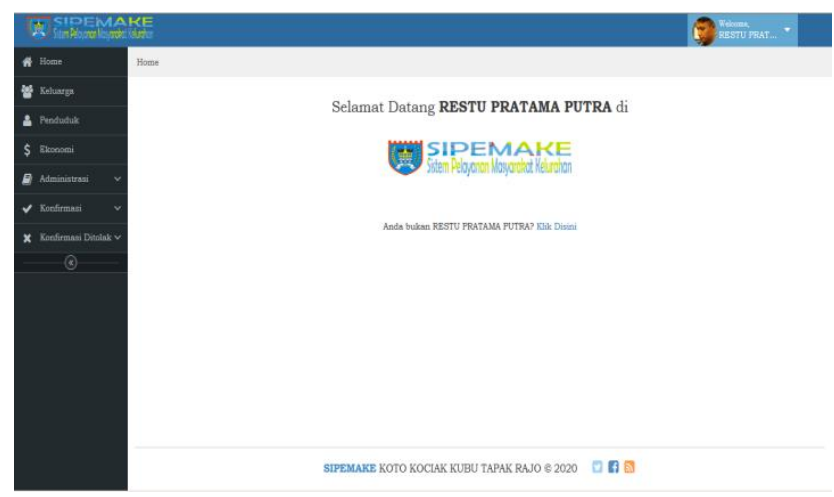

\section{Hasil Halaman Home Bagian Umum}

Gambar 17.Hasil Halaman Home Pemerintahan

Pada interface halaman home bagian umum terdiri dari menu home, perangkat desa, register surat, agenda surat, konfirmasi, dan konfirmasi ditolak. Menu perangkat desa berfungsi untuk mengelola data perangkat desa yang masih bertugas dan yang purna tugas.

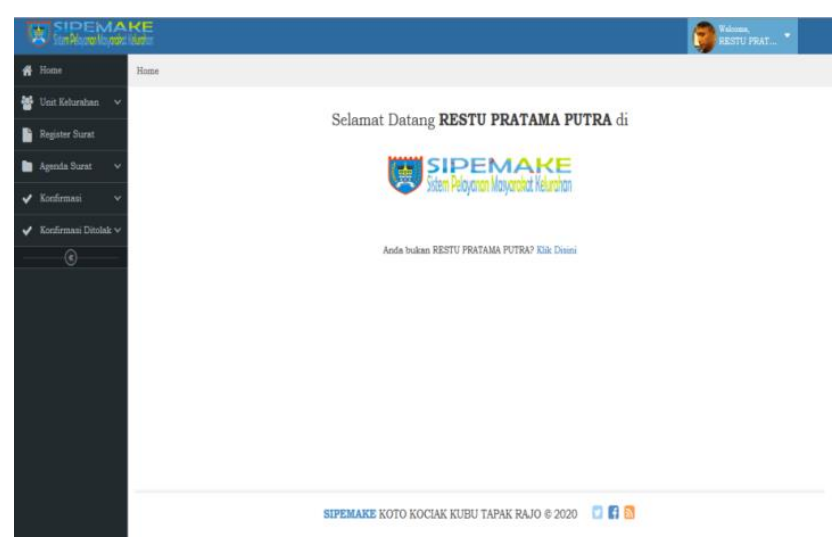

\section{Hasil Halaman Home Kesejahteraan}

Pada interface halaman home kesejahteraan memiliki menu home, ekonomi, dan sosial. Menu ekonomi digunakan untuk mengelola data ekonomi masyarakat desa seperti penghasilan dan pengeluaran. Dari menu ini akan diketahui jumlah penduduk yang mampu dan kurang mampu. Dan menu sosial digunakan untuk mengelola data bantuanbantuan yang diterima oleh masyarakat.

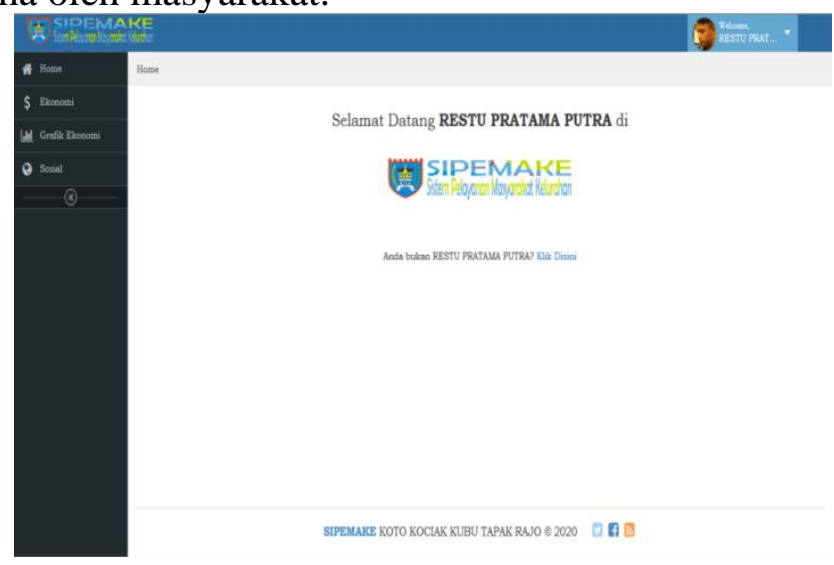

Gambar 19.Hasil Halaman Home Kesejahteraan

\section{Hasil Halaman Home Lurah/Seklur}


Pada interface halaman home lurah dan seklur memiliki menu home, keluarga, penduduk, ekonomi, sosial, administrasi, perangkat desa, register surat, agenda surat, dan konfirmasi.

\section{Hasil Halaman Profil}

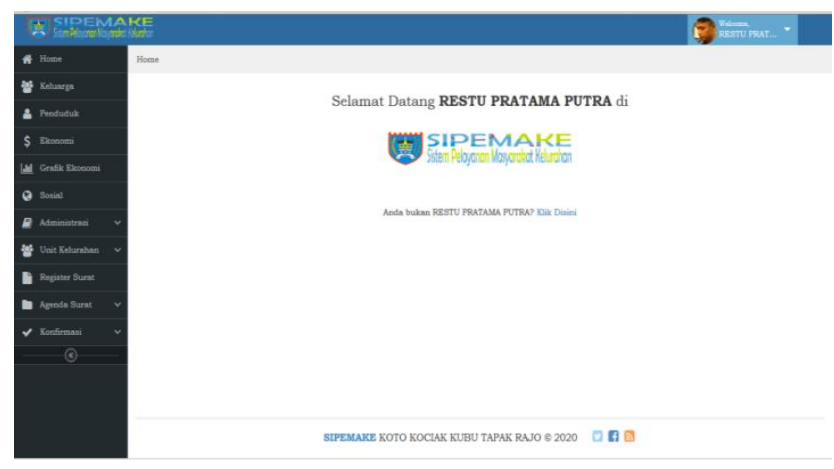

Gambar 20.Hasil Halaman Home Lurah/Seklur

Interface halaman profil merupakan halaman yang menampilkan informasi user yang mengakses sistem. Pada halaman profil juga terdapat tombol edit dan tombol kembali. Tombol edit berfungsi untuk mengubah username dan password dari user dan tombol kembali berfungsi untuk kembali ke halaman sebelumnya.

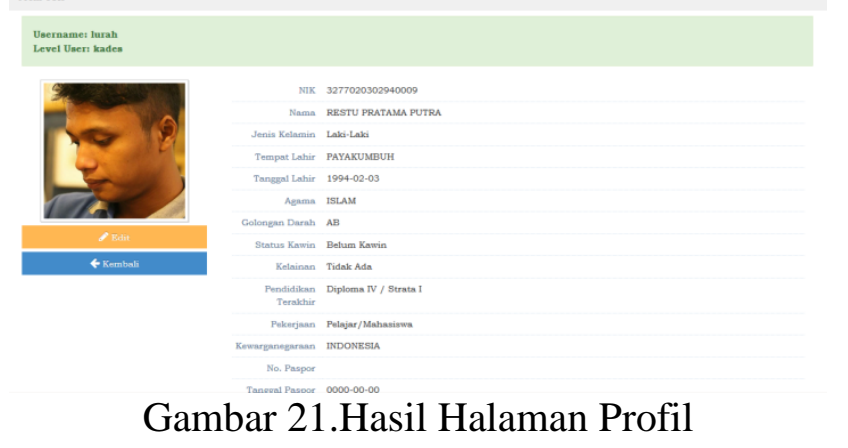

\section{Kesimpulan}

Dari hasil perancangan dan pembangunan Sistem Informasi Pelayanan Masyarakat Kelurahan maka dapat disimpulkan sebagai berikut:

1. Sistem Informasi Pelayanan Masyarakat Kelurahan dirancang dan dibangun berbasiskan web untuk memudahkan para user berinteraksi dengan sistem.

2. Sistem Informasi Pelayanan Masyarakat Kelurahan dirancang dan dibangun untuk mampu mengolah data administrasi kependudukan dan administrasi umum.

3. Sistem Informasi Pelayanan Masyarakat Kelurahan dirancang dan dibangun untuk mampu mewujudkan tertib administrasi Pemerintahan Desa sehingga menghasilkan informasi yang tepat, guna memutuskan suatu keputusan atau kebijakan yang juga tepat oleh Pemerintahan Desa maupun Pemerintahan diatasnya.

Sistem Informasi Pelayanan Masyarakat Kelurahan dirancang dan dibangun untuk mampu mempersingkat waktu dalam melaksanakan pengurusan administrasi pemerintahan desa oleh masyarakat.

Berdasarkan hasil perancangan dan pembangunan Sistem Informasi Pelayanan Masyarakat Kelurahan, penulis menyarankan beberapa hal sebagai berikut: 
1. Pemerintah Kelurahan Koto Kociak Kubu Tapak Rajo diharapkan melakukan penyempurnaan pada sistem yang telah dirancang dan dibangun agar mendapatkan hasil yang lebih baik.

2. Pemerintah Kelurahan Koto Kociak Kubu Tapak Rajo diharapkan melakukan pengembangan sistem sesuai perkembangan zaman, sistem pemerintahan serta disesuaikan dengan amanat peraturan yang berlaku.

3. Pemerintah Kelurahan Koto Kociak Kubu Tapak Rajo juga diharapkan dapat melakukan pengembangan sistem yang mengakomodir kegiatan administrasi lainya pada pemerintahan Kelurahan.

4. Masyarakat dan instansi terkait lainnya diharapkan memberikan masukan untuk pengembangan sistem yang manfaatnya juga dapat dirasakan oleh masyarakat dan instansi tersebut.

\section{Daftar Pustaka}

Ariyadi, B. M., \& Bahar, B. (2017). Model Aplikasi Sistem Pelayanan Terpadu Pada Kantor Kelurahan. Jutisi: Jurnal Ilmiah Teknik Informatika Dan Sistem Informasi, $5(1)$.

Djunaedi, A. (2008). Integrasi E-Government: Tantangan, Kebijakan Dan Implementasi, Seminar Pelayanan Publik Dan E-Government. Seminar Pelayanan Publik Dan EGovernment (Jakarta: Bappenas).

Fathansyah. (2012). Basis Data. Informatika Bandung.

Gaol, C., \& Jimmy, L. (2008). Sistem Informasi Manajemen: Pemahaman dan Aplikasi. Grasindo.

Hidayat, A. (2016). Kinerja Aparatur Dalam Meningkatkan Kualitas Pelayanan Masyarakat Dikelurahan Pelabuhan Kota Samarinda. 4, 12.

Ibrahim, A., Rifai, A., \& Oktarina, L. (2016). RANCANG BANGUN APLIKASI PENCATATAN DATA KEPENDUDUKAN KELURAHAN PAHLAWAN BERBASIS WEB. JSI: Jurnal Sistem Informasi (E-Journal), 8(1), Article 1. https://ejournal.unsri.ac.id/index.php/jsi/article/view/3628

Muslihudin, M., \& Oktafianto. (2008). Analisis dan Perancangan Sistem Informasi Menggunakan Model Terstruktur dan UML. Penerbit Andi.

Noviyanto, F., Setiadi, T., \& Wahyuningsih, I. (2014). IMPLEMENTASI SIKADES (SISTEM INFORMASI KEPENDUDUKAN DESA) UNTUK KEMUDAHAN LAYANAN ADMINISTRASI DESA BERBASIS WEB MOBILE. Jurnal Informatika, 8(1), Article 1. https://doi.org/10.26555/jifo.v8i1.a2084

Republik Indonesia. (2004). Undang-Undang Republik Indonesia Nomor 32 Tahun 2004 Tentang Pemerintahan Daerah.

Setianto, S.H, A. Y., Jehani, S.H, L., Budiman, S.Ag, N., Jehadun, SE, L., \& N, A. (2009). Panduan Lengkap Mengurus Perijinan \& Dokumen Pribadi,Keluarga \& Bisnis. Niaga Swadaya, Jakarta.

Subhan, M. (n.d.). Analisis Perancangan Sistem. Lentera Ilmu Cendikia, Jakarta.

Susartono. (2006). E-Government Di Indonesia. Jurnal Ilmu Administrasi Publik, 2(1), 20. 